\title{
Air temperature in high-altitude areas as exemplified by the Tatra Mountains
}

\section{Krzysztof Jurczak}

Institute of Meteorology and Water Management - National Research Institute, Poland

Stanisław Kędzia

Institute of Geography and Spatial Organization, Polish Academy of Sciences

\begin{abstract}
The climate of a high-altitude postglacial cirque, such as Kozia Dolinka, is conducive to the occurrence of permafrost. Both the depth of permafrost and the area it covers, as well as the presence of year-round snow patches, can serve as indicators for assessing the impact of global warming on the climate of mountains, including the Tatras. With few meteorological stations to survey the remote and inaccessible high-altitude areas of the Tatra Mountains, any research must rely on measurements spanning limited time periods. Against this background, the 5-year series of temperature measurements from the Kozia Dolinka cirque obtained by the Institute of Geography and Spatial Organization of the Polish Academy of Sciences (IGiPZ PAN) can be used to analyze air temperature patterns on concave and convex terrain forms in the alpine climate zone if compared to the results of measurements from stations of the State Hydrological and Meteorological Service located nearby, i.e. the Kasprowy Wierch HighMountain Meteorological Observatory and the Hala Gąsienicowa Nival Research Station of the Institute of Meteorology and Water Management, National Research Institute (IMGW-PIB). This study confirms that there is a relationship between air temperature and the formation and duration of snow cover on concave and convex terrain forms. It also reveals a hitherto unknown fact that concave terrain forms, i.e. postglacial cirques, of the alpine zone have milder thermal conditions in winter than convex terrain forms. The analyses highlight the need for further, more detailed research using modern automated meteorological stations.
\end{abstract}

Keywords

Air temperature, concave and convex forms, Tatras, permafrost.

Submitted 21 September 2021, revised 20 December 2021, accepted 27 December 2021

DOI: $10.26491 / \mathrm{mhwm} / 145366$

\section{Introduction}

The last Tatra glaciers were small glaciers situated in, and often hanging, postglacial cirques at high altitudes (Fig. 1, 3) and melted at the end of the Venediger period, i.e. about $8.3 \mathrm{ka} \mathrm{BP} \mathrm{(Baumgart-Kotarba,}$ Kotarba 2001a-b). Currently, these cirques only contain glacierets and perennial or seasonal snow patches (e.g. Gadomski 1926; Wdowiak 1959, 1961a-b; Kondracki 1978; Jania 1988; Wiślińscy 1991, 1993; Kędzia 1993; Gądek 2002). In some of them, e.g. the Kozia Dolinka cirque, the presence of permafrost has been found (e.g. Kędzia et al. 1998; Mościcki, Kędzia 2001; Kędzia 2004). Glacierets and perennial snow patches are mainly supplied by avalanches and the transportation of snow from rock faces by the wind. Altitude and shading also play a role in contributing to permafrost. Although research on perennial snow patches has been conducted for at least 70 years (Milata 1949) and that on permafrost for about 25 years (Dobiński 1996a-c), measurements of air temperature in high-altitude cirques are rare. A short series of air temperature measurements were recorded in the Kozia Dolinka valley in the 1960s by Hess and his students (Kłapa 1963). In the following years, research into the microclimate, this time of the Mięguszowiecki Kocioł cirque, was conducted by geographers from the University of Warsaw Scientific Society (Gutry-Korycka 1967; Wdowiak 1961a-b), followed by Lublin geographers under the leadership of 
Wiśliński (Wiślińscy 1991). However, there are no known publications by these authors which compare the temperature of postglacial cirques with convex forms located at similar altitudes (e.g. Kasprowy Wierch High-Mountain Meteorological Observatory). Only Hess (1965) found that large-scale concave forms, such as intramontane basins, have a lower average annual temperature (by about $1^{\circ} \mathrm{C}$ ) than convex forms at a similar altitude. When investigating the climatic conditions of patches of permanent snow in 1991, Kędzia (1993) completed two several-day series of measurements of air temperature in the Kocioł Mięguszowiecki cirque and compared them with data from the Kasprowy Wierch High-Mountain Meteorological Observatory. He found that in the absence of clouds in the morning, when direct radiation reached the bottom of the cirque, the air temperature in the cirque was higher than that recorded on Kasprowy Wierch. The Kocioł Mieguszowiecki cirque was also warmer than Kasprowy Wierch at times of persistence of high or complete cloud cover and moderate or strong wind. In the remaining times of the day, air temperature in the cirque in question was lower than that on Kasprowy Wierch. The air temperature in the Kocioł Mięguszowiecki cirque was also strongly influenced by three patches of firn ice (Kędzia 1993). In 2011, Gądek initiated air temperature measurements in the Kocioł Mięguszowiecki cirque (oral information in 2019), but no study of these measurements has been released to date. In 2004, Mościcki (2010a-b) began measuring air temperatures in the Kozia Dolinka and Świnicki Kocioł cirques. Unfortunately, owing to the non-standard measurement method employed (at a height of below $2 \mathrm{~m}$ ), it cannot be compared with other measurements, which are typically taken at $2 \mathrm{~m}$ above the ground.

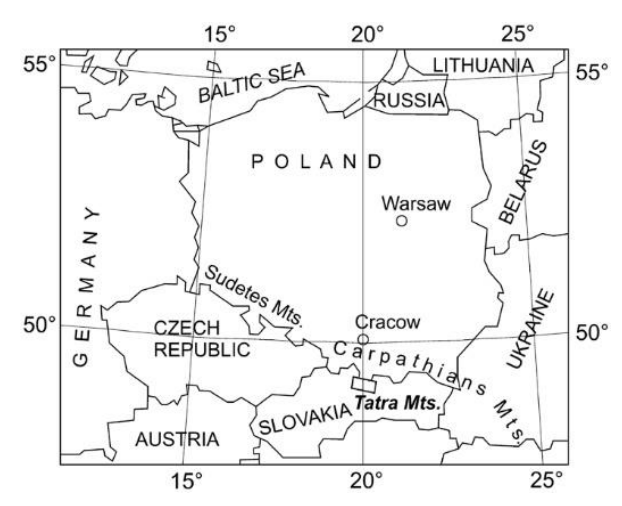

Fig. 1. Tatra Mountains in Europe.

The climate of a high-altitude postglacial cirque, such as Kozia Dolinka, is also conducive to the formation and retention of permafrost (Li et al. 2016; Wang et al. 2018). Both the depth of such permafrost and the area it covers, as well as the presence of year-round snow patches, can serve as indicators for assessing the impact of global warming on the climate of the mountains, including the Tatras (IPCC 2001, 2007, 2013, 2014, 2019).

Despite an array of publications focusing on the various forms of ground relief and the processes present in high-altitude postglacial Tatra cirques (Dąbrowska 2015), their microclimate has not yet been properly investigated. The short series of measurements that exist are insufficient for accurate determination of the average annual air temperature and for a detailed comparison of postglacial cirques with convex forms 
(ridges, peaks), as represented by the Kasprowy Wierch High-Mountain Meteorological Observatory, a benchmark station for the High Tatras. Previous attempts to characterize the microclimate of high-altitude postglacial cirques have amounted to estimates - rather than actual determinations - of average annual air temperatures on the basis of a set of measurements restricted by major terrain-related difficulties. When covered by snow, the Kocioł Mięguszowiecki cirque is not only frequented by avalanches from above, but - due to its low slope angle - also accumulates large amounts of snow that spills in avalanches moving further downslope. The constant slow movement of the snow cover down the slope further complicates obtaining measurements, especially in spring. Even masts made of thick aluminum pipes with a diameter of c. $5 \mathrm{~cm}$ are bent and knocked down. Additionally, the bottoms of the postglacial cirques and the lower sections of slopes tend to accumulate a deep snow cover up to several meters thick (e.g. approx. $6 \mathrm{~m}$ in the Kozia Dolinka valley). As a result of such substantial accumulations of snow, for several winter months sensors measure the temperature of the snow, opposed to that of the air, and regular maintenance of the sensors in wintertime is practically impossible. Comparing temperatures supplied by automatic stations installed within postglacial cirques, with data from the Kasprowy Wierch High-Mountain Meteorological Observatory (Fig. 2), must be preceded by quality control, otherwise it may can lead to erroneous conclusions. The reason may be limitations in the possibility of supervising the conditions of exposure of instruments and the frequency of service activities in an unguarded place (postglacial cirque) and in a meteorological station with specialist staff.

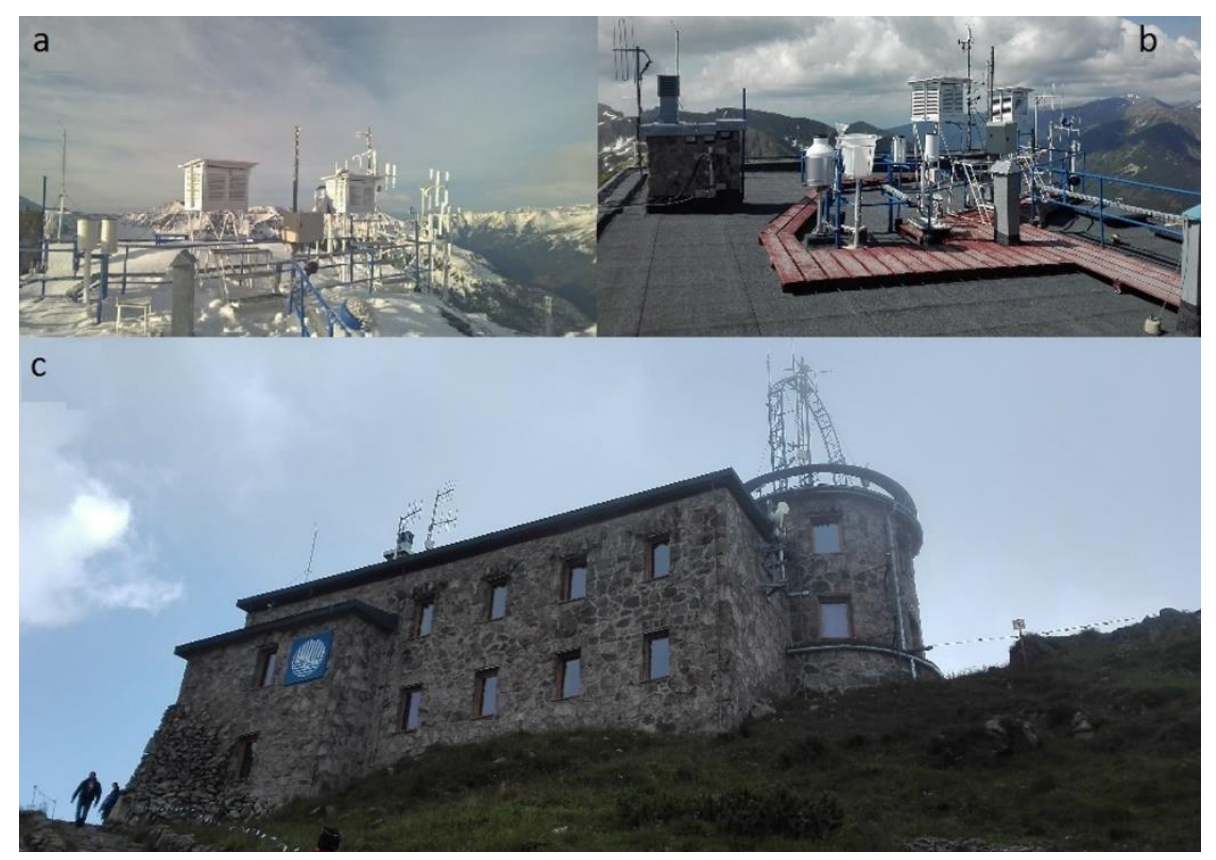

Fig. 2. IMGW-PIB Kasprowy Wierch High-Mountain Meteorological Observatory: a) meteorological instruments in winter setting, b) meteorological instruments in summer setting, c) observatory building (source IMGW-PIB).

In this paper, air temperatures of the Kozia Dolinka cirque measured in 2004-2008 are compared to those from the Kasprowy Wierch High-Mountain Meteorological Observatory. Although the series of measurements from the Kozia Dolinka cirque has numerous gaps in the warm period of the year, it is the only 
such long series of data from a small Tatra postglacial cirque that has been studied to date. The purpose of this paper is to more accurately define the microclimate of small high-altitude postglacial cirques, and to compare it with the microclimate of convex landforms, namely peaks. The paper also attempts to determine to what extent standard air temperature measurements reflect the actual variability of the microclimate in this type of high-mountain area.

\section{Study area}

A postglacial cirque approximately $500 \mathrm{~m}$ and $100 \mathrm{~m}$ wide in the Sucha Woda Valley, namely Kozia Dolinka, whose bottom lies at an altitude of 1930-1950 m (Fig. 3), was selected as the study area. The cirque opens towards the north-east, and the peaks that surround it reach c. $2300 \mathrm{~m}$. The rocky slopes and walls are incised by deep gullies with large, but poorly fragmented talus cones formed at their mouths (Fig. 4). The snow cover, both on the bottom and in the lower sections of the slope, is several meters thick, and only disappears in the first half of June.

In the depressions, firn patches persist until July, and occasionally until August. Very small patches of firn ice may persist in gully mouths and at the interface between rock faces and screes until September. Permafrost occurs in the talus cones under Kozi Wierch and Kozie Czuby (Kędzia et al. 1998; Mościcki, Kędzia 2001; Kędzia 2004).

Finding the right spot to install the station posed a huge problem. The most interesting place for measuring air temperatures is the lower area of the scree near Kozi Wierch, where the permafrost is the thickest. This area is only exposed to direct solar radiation for roughly half of the year. However, given the proximity of the tourist trail, great thickness of the snow cover and likelihood of snow avalanches, the idea of positioning the station there was abandoned. After observing the formation of the snow cover in Kozia Dolinka for several years it was concluded that the only spot where the station would last and measure air, rather than snow temperature was a rocky outcrop between the upper sections of the talus cones beneath the Kozi Wierch and the Kozie Czuby peaks. The outcrop lies at about $2010 \mathrm{~m}$ a.s.l. and around $60 \mathrm{~m}$ above the bottom of the adjacent valley. Kędzia installed an air temperature measuring station here in 2014. Even though the area has no permafrost and its location, at $60 \mathrm{~m}$ above the bottom of the cirque, implies that it is not the coldest spot during temperature inversion period, the area nevertheless reflects the thermal conditions of the concave landform, and is suitable for studying differences in thermal conditions with the neighboring peaks and ridges. This includes the conditions that prevail at the Kasprowy Wierch High-Mountain Meteorological Observatory.

The results of temperature measurements from Kozia Dolinka were compared with the measurements of the Kasprowy Wierch High-Mountain Meteorological Observatory, which lies at an altitude of $1991 \mathrm{~m}, c$. $20 \mathrm{~m}$ below the Kozia Dolinka station, but at the top of a peak (a convex form). The temperature is measured in a meteorological cage mounted on the roof of the building (Fig. 2). 


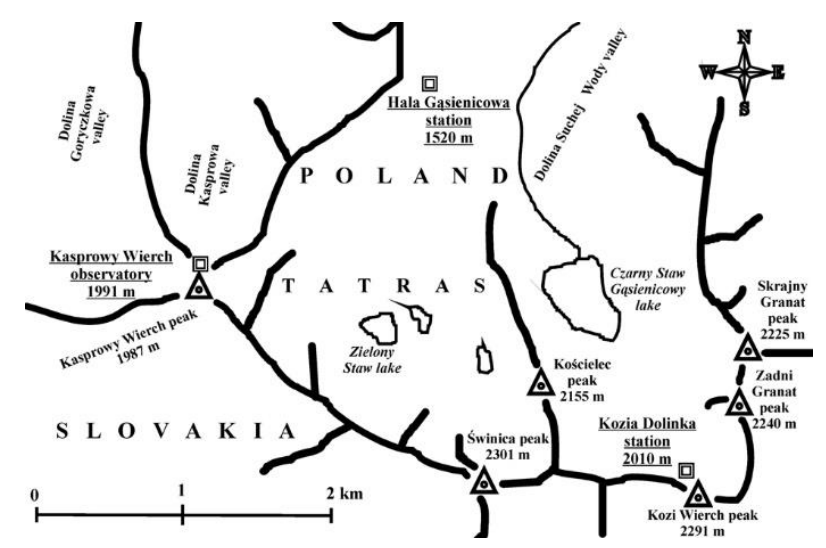

Fig. 3. Study area (ridge map): Kozia Dolinka - Kasprowy Wierch - Hala Gąsienicowa.

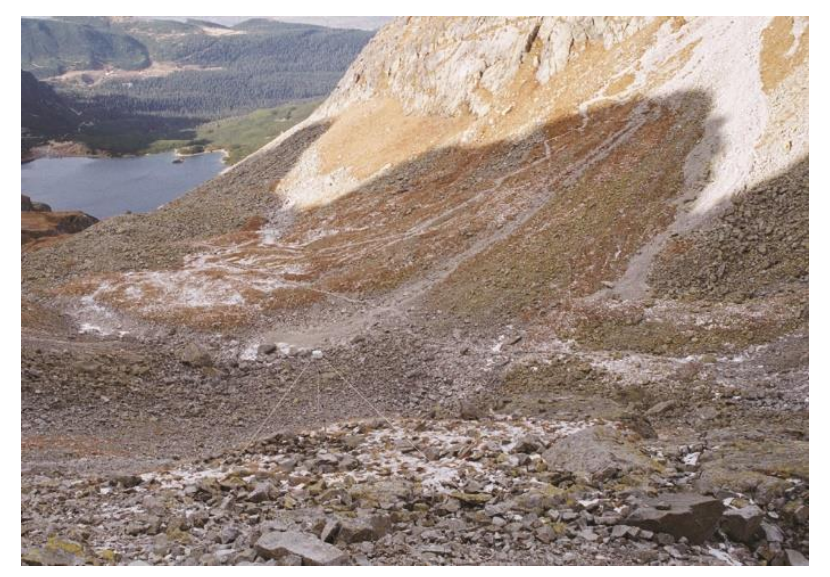

Fig. 4. Kozia Dolinka station.

\section{Research methods}

Air temperatures in the Kozia Dolinka valley were measured at a height of $2 \mathrm{~m}$ above the ground, using Onset Computers digital HOBO Pro data loggers, fitted with thermistors with a measurement uncertainty of $\pm 0.2^{\circ} \mathrm{C}$ and resolution of $0.02^{\circ} \mathrm{C}$ (Fig. 4). Before they were installed onsite, each logger had been calibrated to an accuracy of $0.1^{\circ} \mathrm{C}$, and checked after it was removed from the measuring site. The measurements spanned the period from 14 October 2004 to 29 January 2009. Measurements were logged daily on an hourly basis. The thermistor (digital thermometer) was placed in a radiation shield, which protected it against precipitation and direct solar radiation. The maximum thickness of the snow cover at the measuring site (in the years 2004-2009) usually remained below $1 \mathrm{~m}$ as a result of snow being blown away by the wind. Despite the relatively low snow cover in spring (twice in June and once in May), the mast of the station would be knocked down and destroyed by the dense snow that moved downslope. As a consequence, there are gaps in the data series in each year.

Temperatures at the IMGW-PIB Kasprowy Wierch High-Mountain Meteorological Observatory were measured by Vaisala temperature sensors integrated into an automatic MAWS 301 weather station. The sensors were placed in a meteorological cage mounted on the roof of the building $2 \mathrm{~m}$ above its surface (Fig. 2). They had valid calibration certificates and were additionally checked using portable calibration standards at six-month intervals. The measurement results were recorded in one-minute steps. This paper 
uses the data recorded at each full hour. The sensor's exposure was checked on an ongoing basis and adjusted throughout the day, if necessary, by observers in the observatory.

The data on snow cover duration were based on the measurements at the Hala Gasienicowa Nival Research Station of the IMGW-PIB. Unlike the Kasprowy Wierch High-Mountain Meteorological Observatory, the Hala Gasienicowa Station is free of disturbances to the thickness of the snow cover resulting from the transportation of snow by winds. The Hala Gasienicowa Station, which has the status of a second-order synoptic station (from 1 January 2019, previously a third-order climate station) is the highest situated IMGW-PIB station in the Tatras (1520 $\mathrm{m}$ a.s.l.), and the snow cover is measured in a meteorological garden.

\section{Results}

Despite the gaps in the data series, mainly in the summer, there is clear seasonality in the average monthly temperatures between Kozia Dolinka and Kasprowy Wierch (Figs. 5, 6). In late autumn, winter and early Spring (Fig. 5) Kozia Dolinka is generally warmer. The difference in the average monthly air temperature between these two sites increases with the number of days with snow cover and decreases as the snow cover recedes. The greatest difference in average monthly temperatures was recorded in March 2006, when Kozia Dolinka was warmer than Kasprowy Wierch by $0.8^{\circ} \mathrm{C}$. The situation reversed in September (from June to August, the station was damaged after heavy snowfall in late May and the first decade of June). At that time the snow cover had already melted on the ridges and peaks, while the shaded slopes in Kozia Dolinka were still snow-covered, the Kozia Dolinka cirque was $0.2^{\circ} \mathrm{C}$ colder. It was the coldest in April 2007, when the difference in the average monthly temperatures between Kozia Dolinka and Kasprowy Wierch reached $0.6^{\circ} \mathrm{C}$. This was associated with very early thawing of the winter snow cover across the Tatras, where snow could only be found in high lying and shaded concave landforms. A similar situation occurred in June-August 2008 , when the temperature difference reached $0.5^{\circ} \mathrm{C}$. The least pronounced differences in temperature between the stations in question were recorded in autumn 2005. This was likely driven by snowfall in August and the following months, as well as the early formation of snow cover throughout the Tatras. This eliminated temperature differences arising from the influences of active surfaces, which normally behave in different ways in autumn (especially in connection with the presence of snow patches in concave forms and the absence thereof on convex ones). 


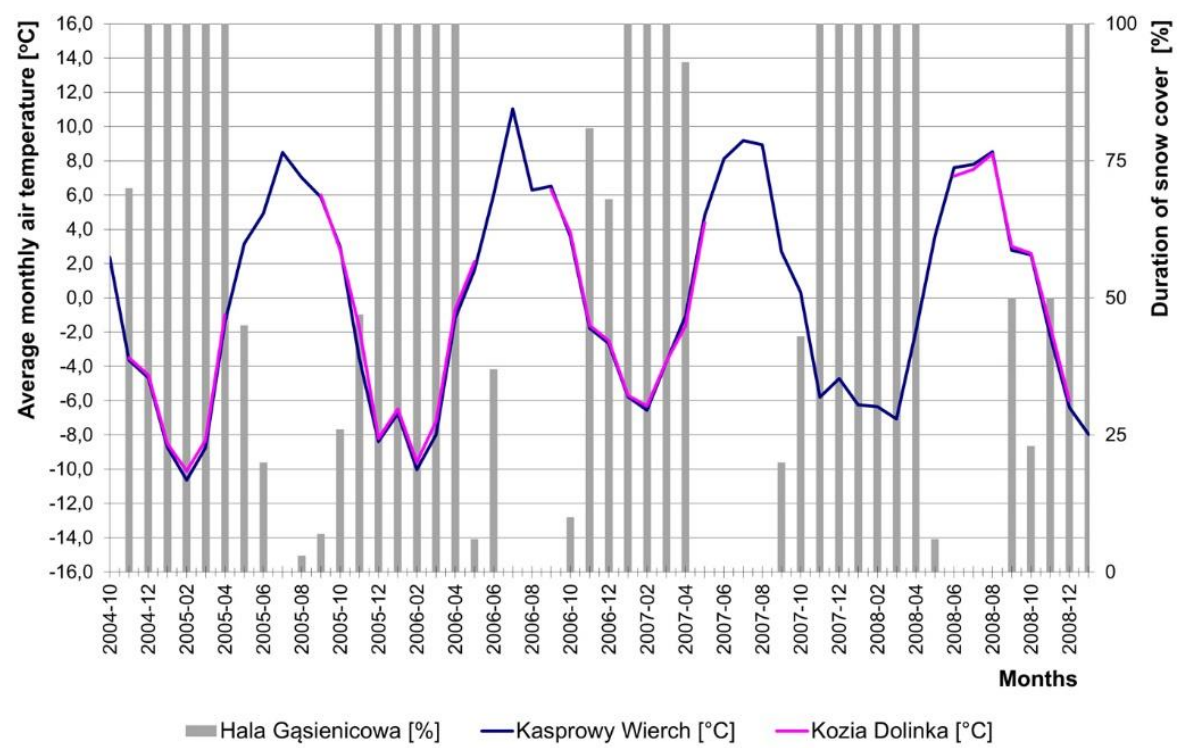

Fig. 5. Average monthly air temperature on Kasprowy Wierch and in Kozia Dolinka, and duration of snow cover on Hala Gąsienicowa.

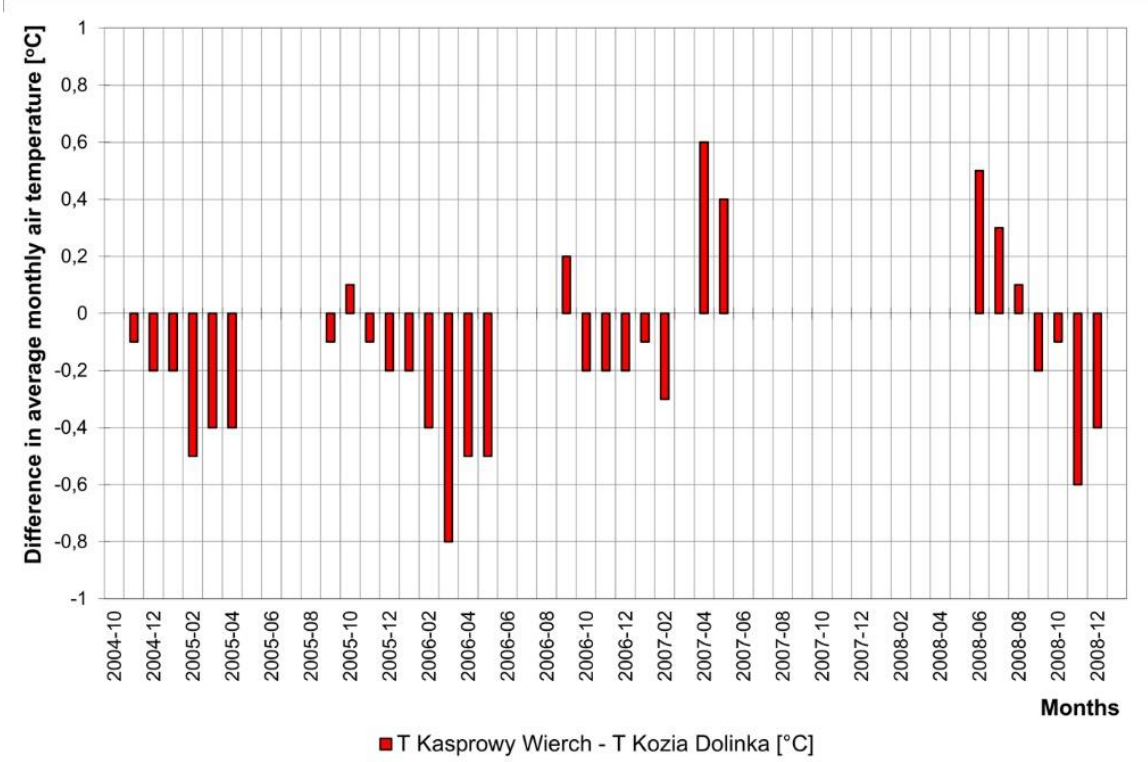

Fig. 6. Difference in average monthly air temperature between Kasprowy Wierch and Kozia Dolinka. Negative values occur when the temperature in Kozia Dolinka is higher than on Kasprowy Wierch.

While the most pronounced differences between Kozia Dolinka and Kasprowy Wierch in the average monthly air temperature were mainly recorded in the second half of the winter (February-March), the largest differences in the average monthly minimum temperature were chiefly observed in autumn and in the first part of winter (October-November). The most noticeable differences in the average monthly minimum temperature in the study period were recorded in autumn 2005 and winter 2006 (Figs. 7, 8). In absolute terms, the largest difference and duration of snow cover on Hala Gąsienicowa was recorded in November 2005, when the average monthly minimum temperature in the Kozia Dolinka cirque was higher 
and amounted to $-4.7^{\circ} \mathrm{C}$, while that on Kasprowy Wierch was $-5.6^{\circ} \mathrm{C}$. By contrast, the smallest differences in the average monthly minimum temperature were recorded in the winter of 2004. Lower values of the average monthly minimum temperature in Kozia Dolinka were chiefly recorded in winter and spring. The difference did not exceed $0.3^{\circ} \mathrm{C}$.

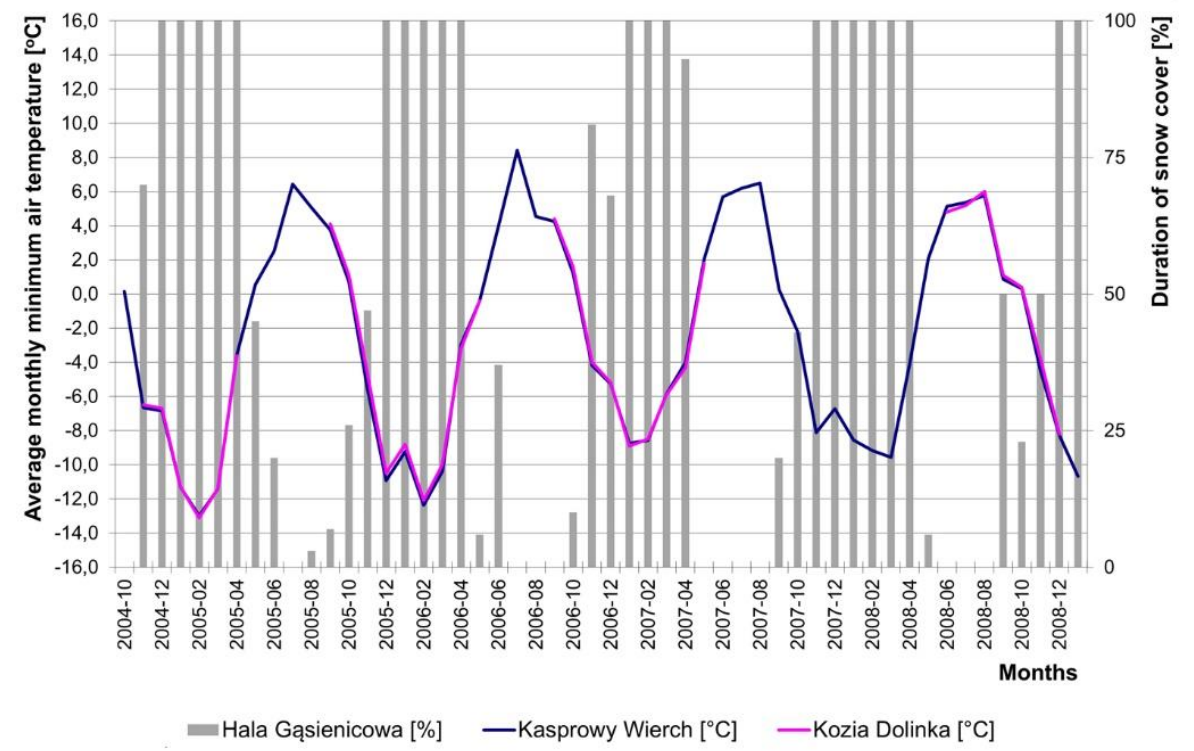

Fig. 7. Average monthly minimum air temperature on Kasprowy Wierch and in Kozia Dolinka, and duration of snow cover on Hala Gąsienicowa.

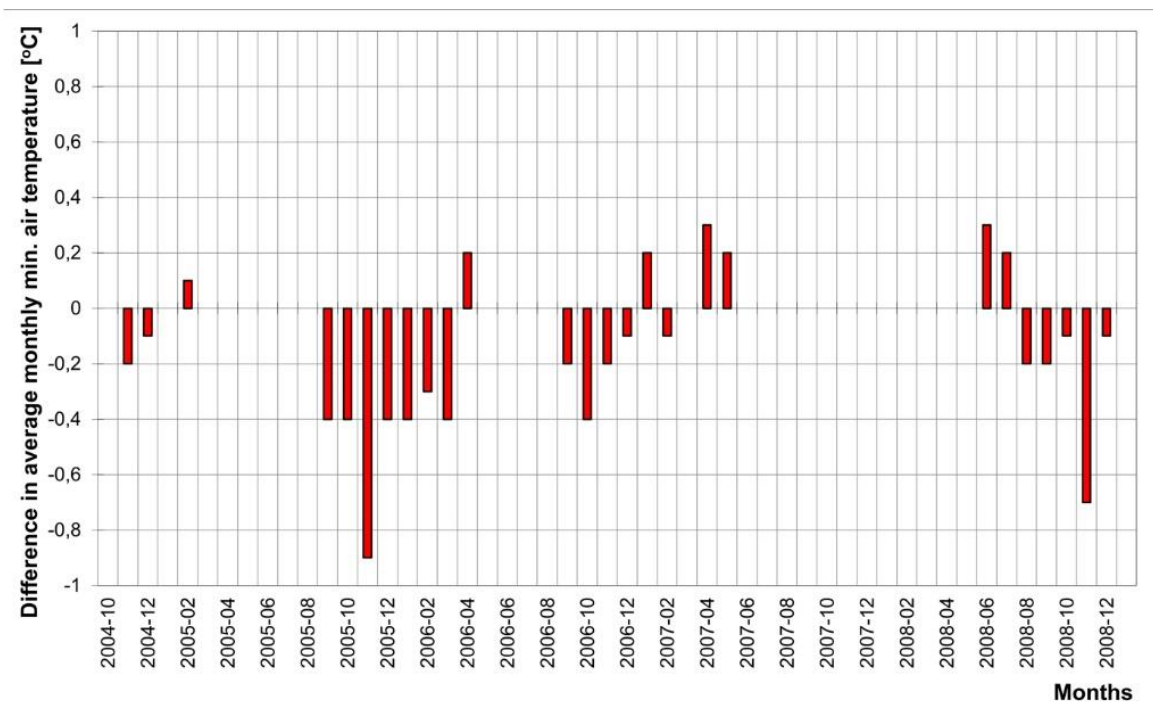

-T Kasprowy Wierch - T Kozia Dolinka $\left[{ }^{\circ} \mathrm{C}\right]$

Fig. 8. Difference in average monthly minimum air temperature between Kasprowy Wierch and Kozia Dolinka. Negative values occur when the temperature in Kozia Dolinka is higher than on Kasprowy Wierch.

However, the largest differences between Kozia Dolinka and Kasprowy Wierch were observed for the average monthly maximum temperature (Figs. 9, 10). In April 2006, the average monthly maximum temperature in Kozia Dolinka was $3.1^{\circ} \mathrm{C}$ higher than on Kasprowy Wierch, while the year before, i.e. in April 
2005 , this was $2.5^{\circ} \mathrm{C}$. In the winter of 2007 , the greatest differences reached $0.6^{\circ} \mathrm{C}$. Large differences between the stations were also observed in September 2006 and 2008, when the average monthly maximum temperatures in the Kozia Dolinka cirque were $1.1^{\circ} \mathrm{C}$ and $0.7^{\circ} \mathrm{C}$ higher, respectively. Values of average monthly maximum temperature which were lower than on Kasprowy Wierch occurred twice in the warm season (in September and October 2005 and in June-August 2008), and once in winter (April 2007). The difference in recorded values fluctuated around $0.5^{\circ} \mathrm{C}$.

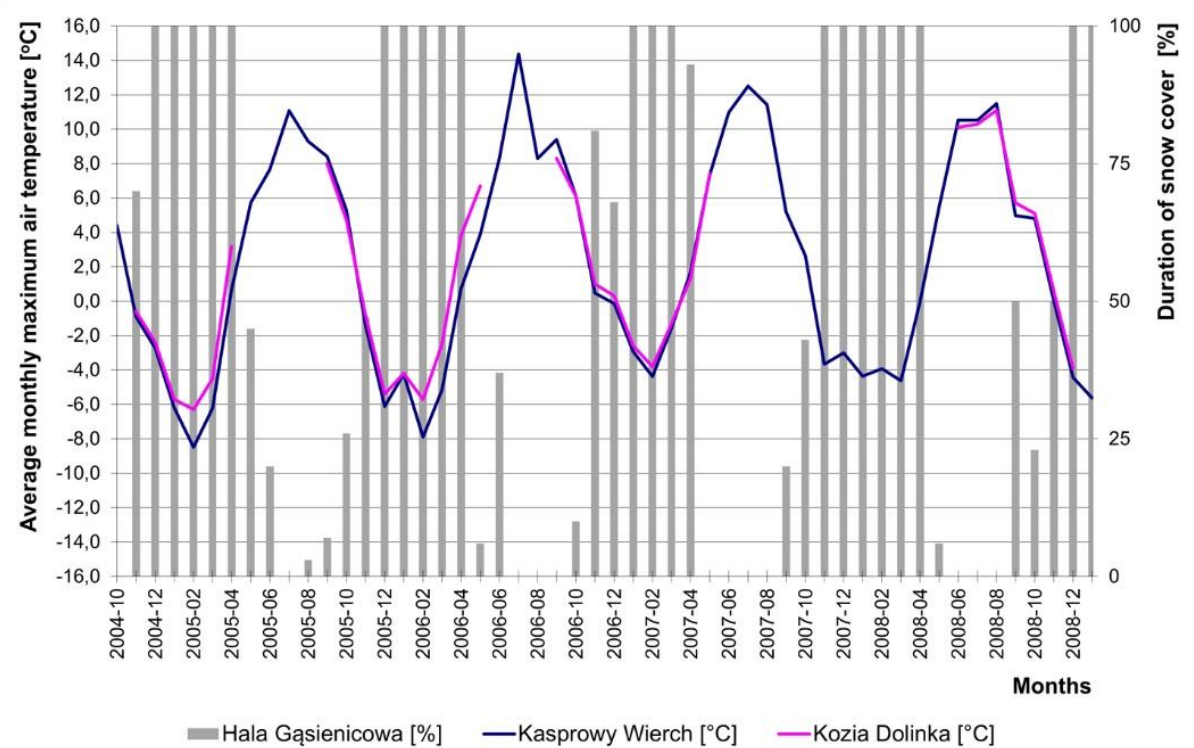

Fig. 9. Average monthly maximum air temperature on Kasprowy Wierch and in Kozia Dolinka, and duration of snow cover on Hala Gąsienicowa.

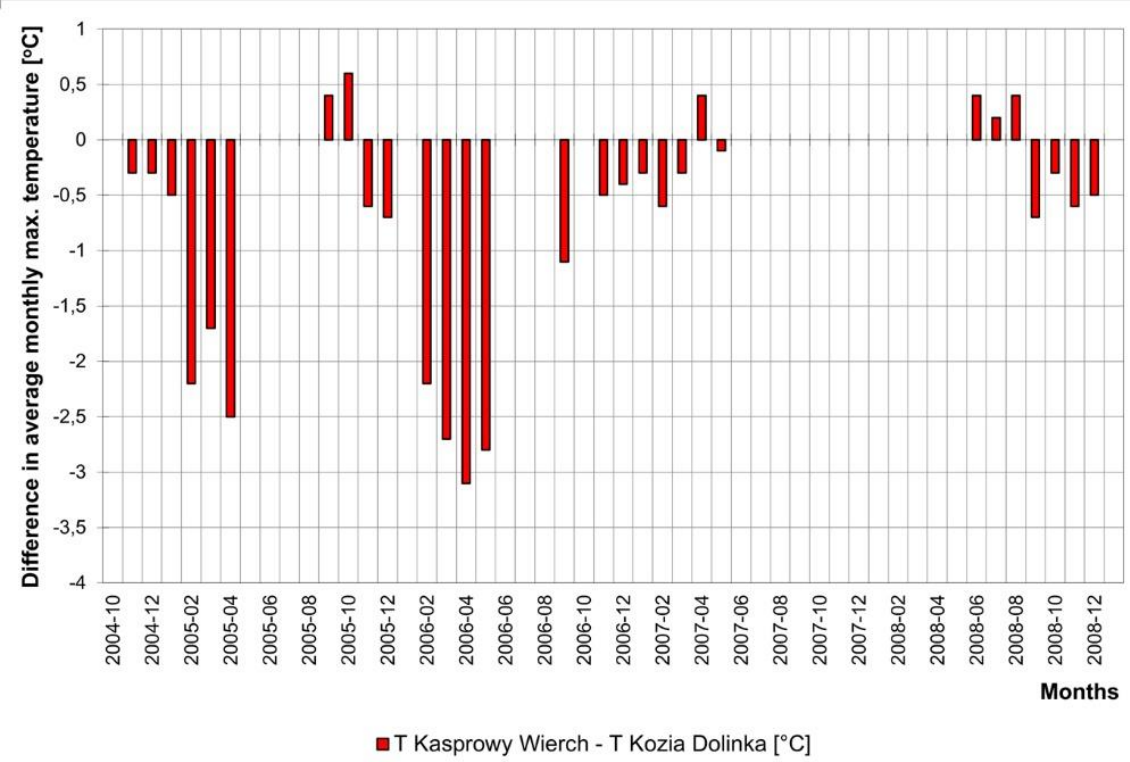

Fig. 10. Difference in average monthly maximum temperature between Kasprowy Wierch and Kozia Dolinka. Negative values occur when the temperature in Kozia Dolinka is higher than on Kasprowy Wierch. 


\section{Discussion}

Our analysis of the trend in the average monthly air temperature and the average monthly maximum and minimum temperatures, as well as of periods when snow cover builds up and disappears, has revealed that the Kozia Dolinka cirque is warmer than Kasprowy Wierch for most of the year, except for the period when the snow cover retreats. At such times, the very thick snow cover, formed by snow blown into Kozia Dolinka from rock faces, lasts until June with some snow patches remaining in place until September. By contrast, at the summit of Kasprowy Wierch, where the IMGW-PIB High-Mountain Meteorological Observatory is located, the snow cover is much thinner and disappears faster than in Kozia Dolinka as a result of the snow blowing away. There are no long-lying snow patches on Kasprowy Wierch, which would have a cooling effect on the environment and thus lower the air temperature by absorbing energy for the melting and sublimation of snow. The long duration of the snow cover and snow patches in Kozia Dolinka causes the air temperature to be lower here than on Kasprowy Wierch in late spring and early summer, when the winter snow cover has already melted on Kasprowy Wierch. Kozia Dolinka is cooler than Kasprowy Wierch during the thawing of the winter snow cover. There are situations when fresh snow cover forms after the winter cover has already disappeared, e.g. at the end of May or at the beginning of June. During the thawing of such 'summer' snow cover, Kozia Dolinka remains much cooler than Kasprowy Wierch.

The most substantial differences in average monthly minimum temperature between the stations occur in autumn: in October or November, when higher minimum temperatures are observed in Kozia Dolinka. It is difficult to determine the underlying causation without additional research. Apart from the increased effect of the foehn wind, the most likely reason is the dissipation of heat by the rocky slopes surrounding the Kozia Dolinka valley, which are yet to be covered by an insulating layer of snow cover, whilst the snow cover on Kasprowy Wierch has already been formed.

Surprisingly, the highest temperature differences between Kozia Dolinka and Kasprowy Wierch are characterized in the average monthly maximum temperature. The temperature at the warmest time of the day is crucial for the duration of snow patches in Kozia Dolinka. However, it must be remembered that this is caused by feedback since, on the one hand, the presence of snow patches decreases the temperature in connection with the utilization of energy to melt and sublime the snow, and on the other, lowered temperatures slow down these processes and cause the snow cover to persist. A clear inverse relationship is observable, namely that the persistence of snow cover in Kozia Dolinka when it is absent on Kasprowy Wierch. This usually happens in spring and early summer; as snow cover is formed- an increase in the difference in maximum temperature between the stations and generally in higher maximum temperatures on Kasprowy Wierch are initiated.

Current knowledge of the climate of high-altitude postglacial cirques in the Tatras suggests that the air temperature in such concave, strongly shaded landforms with long-lying snow cover is significantly lower 
all year round than the air temperature on convex landforms. This was the conclusion, inter alia, of research by Hess (1965). Admittedly, two series of several-day-long measurements in the Kocioł Mięguszowiecki cirque carried out by Kędzia (1993) demonstrated that in some weather situations highaltitude postglacial cirques may be warmer than convex forms, but it seemed unlikely for a concave feature to be warmer than a convex one for over half a year, and even less so in the cold half of the year. That Kasprowy Wierch would be cooler during winter by as much as $0.8^{\circ} \mathrm{C}$ than Kozia Dolinka seemed even more unlikely. Based on the series of several-year-long measurements used in the present study, which is, unfortunately, incomplete, it is difficult to clearly ascertain the underlying causes. The likely reason is the fact that the station in Kozia Dolinka is situated about $60 \mathrm{~m}$ above the bottom of the valley, i.e. above the area where cold air is likely to stand. Another relevant factor could be the location where the air temperature is measured on Kasprowy Wierch, with the thermometers placed on the roof of a two-story building, i.e. about $8 \mathrm{~m}$ above the ground. Positioning the thermometers in this way, especially on the top of a mountain, may lower the value of the measured air temperature. Temperature differences may also be caused by natural conditions, including the albedo of snow-covered vertical rock faces and the inflow of warmth from the heated vertical rocks towards the valley. This culminates in small, high-altitude and concave forms to have a higher temperature in winter than unprotected convex forms, namely peaks.

\section{Conclusions}

In the cool half of the year, the IMGW-PIB High-Mountain Meteorological Observatory located on the summit of Kasprowy Wierch records lower thermal indicators than the station in Kozia Dolinka - a small glacial cirque located at a similar altitude, as reflected by the average monthly air temperature and the average monthly maximum and minimum temperatures.

The pattern of average monthly air temperature in the warm season of the year shows a relationship with periods of thawing of winter and seasonal snow cover.

With no additional measurements of the heat balance, standard measurements of air temperatures in high mountains are not sufficient to unambiguously explain the observed patterns. Consequently, there is a need for further and more detailed investigation of the topoclimate of postglacial high-altitude cirques and convex forms, such as peaks and ridges, in order to confirm differences in temperature between these forms and identify the underlying causes. In particular, this applies to summer periods, for which the longest gaps in the data series occurred.

The present study confirms the results of previous research, which has corroborated the presence of conditions conducive to the persistence of permafrost in the Kozia Dolinka cirque. Even though Kozia Dolinka is warmer in the cold season than Kasprowy Wierch, the temperature of the warm season and especially the maximum temperature is the key factor in determining permafrost. In Kozia Dolinka, the impact of air temperature on ground temperature in winter is weakened by the presence of a very thick (several meters thick) snow cover that insulates the ground. In the summer, when permafrost undergoes 
ablation, Kozia Dolinka is colder than Kasprowy Wierch, which leads to a conclusion that high altitude postglacial cirques offer more favorable conditions for permafrost than convex forms.

\section{References}

Baumgart-Kotarba M., Kotarba A., 2001a, Deglacjacja Doliny Suchej Wody w Tatrach Wysokich, [in:] Funkcjonowanie geoekosystemów w zróżnicowanych warunkach morfoklimatycznych - monitoring, ochrona, edukacja, A. Karczewski, A.Z. Zwoliński (eds.), Stowarzyszenie Geomorfologów Polskich, Poznań, 73-84.

Baumgart-Kotarba M., Kotarba A., 2001b, Deglaciation in the Sucha Woda and Pańszczyca Valleys in the Polish High Tatras, Studia Geomorfologica Carpatho-Balcanica 35, 7-38.

Dą̧browska K., 2015, Atlas Tatr - Przyroda nieożywiona, TPN, Zakopane, 28 pp.

Dobiński W., 1996a, Poszukiwanie zmarzliny w Tatrach z zastosowaniem metod geofizycznych i analizy klimatycznej, [in:] Osady i formy czwartorzędowe współczesnego i plejstoceńskiego zlodowacenia półkuli północnej - sympozjum, Poznań, 16-17.

Dobiński W., 1996b, Problem występowania wyspowej zmarzliny w Dolinie Pięciu Stawów Polskich i okolicy w świetle pomiarów temperatury u spodu zimowej pokrywy śnieżnej (BTS), Geographia Studia et dissertationess, 20, Prace Naukowe Uniwersytetu Śląskiego 1552, 15-22.

Dobiński W., 1996c, Występowanie zmarzliny w alpejskim piętrze Tatr Wysokich w świetle badań geofizycznych i analiz klimatycznych, Przyroda Tatrzańskiego Parku Narodowego a Człowiek, 1, Nauki o Ziemi, 140-143.

Gadomski A., 1926, Morfologia glacjalna północnych stoków Wysokich Tatr, Nakład B. Kotuli, Cieszyn, 140 pp.

Gądek B., 2002, Mass circulation of Mięguszowiecki glacieret in the period 1998-1999, [in:] Przemiany Środowiska Przyrodniczego Tatr, Tatrzański Park Narodowy, Polskie Towarzystwo Przyjaciół Nauk o Ziemi Oddział Kraków, Kraków-Zakopane, 71-75.

Gutry-Korycka M., 1967, Temperatura potoków Tatrzańskich o różnych źródłach zasilania, Przegląd Geograficzny, 39 (3), 577 584.

Hess M., 1965, Vertical climatic zones in the Polish Western Carpathians, Zeszyty Naukowe Uniwersytetu Jagiellońskiego, Prace Geograficzne, 11, $268 \mathrm{pp}$.

IPCC, 2001, Climate Change 2001: The Scientific Basis, [in:] Contribution of the Working Grup I to the Third Assessment Report of the Intergovernmental Panel on Climate Change, J.T. Houghton et al. (eds.), Cambridge University Press, Cambridge, United Kingdom and New York, NY, USA., 881 pp.

IPCC, 2007, Climate Change 2007: The Physical Science Basis, [in:] Contribution of Working Group I to the Fourth Assessment Report of the Intergovernmental Panel on Climate Change, S. Solomon et al. (eds.), Cambridge University Press, Cambridge, United Kingdom and New York, NY, USA, 996 pp.

IPCC, 2013, Climate Change 2013: The Physical Science Basis, [in:] Contribution of Working Group I to the Fifth Assessment Report of the Intergovernmental Panel on Climate Change, T.F. Stocker et al. (eds.), Cambridge University Press, Cambridge, United Kingdom and New York, NY, USA, 1535 pp.

IPCC, 2014, Climate Change 2014: Synthesis Report, [in:] Contribution of Working Groups I, II and III to the Fifth Assessment Report of the Intergovernmental Panel on Climate Change, R.K. Pachauri, L.A. Meyer (eds.), IPCC, Geneva, Switzerland, 151 pp.

IPCC, 2019, Climate Change and Land: an IPCC special report on climate change, desertification, land degradation, sustainable land management, food security, and greenhouse gas fluxes in terrestrial ecosystems, P.R. Shukla, J. Skea, E. Calvo Buendia, V. Masson-Delmotte, H.-O. Pörtner, D. C. Roberts, P. Zhai, R. Slade, S. Connors, R. van Diemen, M. Ferrat, E. Haughey, S. Luz, S. Neogi, M. Pathak, J. Petzold, J. Portugal Pereira, P. Vyas, E. Huntley, K. Kissick, M. Belkacemi, J. Malley (eds.), 864 pp. (in press).

Jania J., 1988, Zrozumieć lodowce, Wydawnictwo Śląsk, 240 pp.

Kędzia S., 1993, Klimatyczne uwarunkowania płatów wiecznego śniegu w Tatrach na przykładzie śnieżnika w Kotle Mięguszowieckim, Uniwersytet Jagielloński, Zakład Klimatologii Instytutu Geografii, Kraków, 69 pp. 
Kędzia S., 2004, Klimatyczne i topograficzne uwarunkowania występowania wieloletniej zmarzliny w Tatrach Wysokich (na przykładzie Koziej Dolinki), Ph.D. thesis, Instytut Geografii i Przestrzennego Zagospodarowania Polskiej Akademii Nauk, Warszawa, 124 pp.

Kędzia S., Mościcki J., Wróbel A., 1998, Studies on the occurrence of permafrost in Kozia Valley (The High Tatra Mts.), [in:] Relief, Quaternery Paleogeography and Changes of the Polar Environment, Polar Session, UMCS Lublin, J. Repelewska-Pękalowa, (ed.), 51-57.

Kłapa M., 1963, Prace Stacji Badawczej Instytutu Geografii PAN na Hali Gąsienicowej w latach 1960 i 1961, Przegląd Geograficzny, 35 (2), 221-237.

Kondracki J., 1978, Geografia fizyczna Polski, Państwowe Wydawnictwa Naukowe, Warszawa, 464 pp.

Li J., Sheng Y., Wu J., Feng Z., Ning Z., Hu X., Zhang X., 2016, Landform-related permafrost characteristics in the source area of the Yellow River, eastern Qinghai-Tibet Plateau, Geomorphology, 269, 104-111, DOI: 10.1016/j.geomorph.2016.06.024.

Milata W., 1949, Badania nad polami śnieżnymi w Tatrach, Wierchy, 19, 220-222.

Mościcki J.W., Kędzia S., 2001, Investigation of mountain permafrost in the Kozia Dolinka valley, Tatra Mountains, Poland, Norwegian Journal of Geography, 55 (4), 235-240, DOI: 10.1080/00291950152746586.

Mościcki W.J., 2010a, Temperatura na NE stoku Świnicy i w Koziej Dolince w Tatrach w okresie 2007-2009, [in:] Przyroda Tatrzańskiego Parku Narodowego a Człowiek, Nauki o Ziemi, 1, A. Kotarba (ed), Wydawnictwa Tatrzańskiego Parku Narodowego, Zakopane, 95-102.

Mościcki W.J., 2010b, Temperature regime on northen slopes of Hala Gasienicowa in the Polish Tatra Mountains and its relationship to permafrost, Studia Geomorphologica Carpatho-Balcanica, 42, 23-40.

Wang S., Sheng Y., Li J., 2018, An estimation of ground ice volumes in permafrost layers in Northeastern Qinghai-Tibet Plateau, China, Chinese Geographical Science, 28 (1), 61-73, DOI: 10.1007/s 11769-018-0932-z.

Wdowiak S., 1959, Współczesne resztkowe lodowce firnowe Wysokich Tatr, Przegląd Geologiczny, 7/8, 375-376.

Wdowiak S., 1961, Contemporary cirque glacier in the Grand Mięguszowiecki Cirque at Morskie Oko Lake in the Tatra Mountains, Biuletyn Geologiczny, 1 (1), 87-92.

Wdowiak S., 1961, Współczesny lodowiec karowy w Wielkim Kotle Mięguszowieckim nad Morskim Okiem w Tatrach, Biuletyn Geologiczny, 1/1, 87-92.

Wiślinscy Z.A., 1991, Lubelscy geografowie badają firn i lód w Tatrach, Tatry, 2, 10-13.

Wiślinscy Z.A., 1993, Tatrzański firn i lód w liczbach, Tatry, 4, 26-28. 